\title{
The Development of MODEREN to Increase Gross Motor Skills of Students with Mild Mental Retardation
}

\author{
Febryansah Gilang Aris Pradana*, Dwi Lorry Juniarisca \\ Jurusan Pendidikan Olahraga \\ Universitas Negeri Surabaya \\ Surabaya, Indonesia \\ *febryansahpradana16060464058@mhs.unesa.ac.id
}

\begin{abstract}
Variations of materials and supporting tools are substantial to the learning of physical education subject which aims to improve the students' gross motor skills. Innovations of equipment which are capable to increase the students' interest in learning are necessary in order to optimize their motor development. This research offers a solution in the form of a model development, a learning-through-games model utilizing modified tools. The development of MODEREN was carried out by using Research and Development design through 4 stages: needs analysis, planning, development, and testing. Data analysis was performed by using descriptive statistic techniques. The results showed that the application of MODEREN model improved the gross motor skills of students with mental retardation. This model increased the student's initiative in learning, hence attempting more of the moves being taught. In addition, through MODEREN tools organization model, students are involved to learn in groups and inciting interactions and cooperation among students throughout the learning process.
\end{abstract}

Keywords: gross motor skill, mental retardation, MODEREN

\section{INTRODUCTION}

Physical education for mentally retarded students require special designs to optimize the development and growth of their motor skills [1-3]. The teaching and learning processes should be modified in accordance to the characteristics of each mentally retarded student who require special attentions regarding their physical, mental, intellectual, emotional, attitude, or social behaviour [4-6]. Caused by central nerve damage [7]. The creation of effective learning environments for exceptional students must involve both regular and special educators who are confronted with countless new challenges and responsibilities [8-10]. Adaptive Physical Learning in extraordinary school is focused on physical fitness and general health, for instance muscle strength exercises, flexibility and students' motoric skills [11-14].

Siswa Budhi Extraordinary School Surabaya to physical education learning is limited to warm-ups, gymnastics, and running activities. On the other hand, the learning method rarely utilizes games, resulting in boredom and decreases students' learning motivation. Another reason for this is the lack of facilities and infrastructure to support learning activities [15]. For example, in the process of physical education learning of jumping movements, the teachers only use rope and in crawling movements, the teacher only uses a chair as learning media. This equipment is considered unattractive and might jeopardize the safety of mentally disabled student. The lack of facilities and infrastructure of physical education causes insufficiency of movement activities for mentally disabled students. It is important to improve their activity, since such would have an impact on their gross motor quality.

One of the alternatives to solve lack of material variations in physical education learning in Siswa Budhi Extraordinary School Surabaya Surabaya is through the application of learning process using the model Motoric Development for Special Children. MODEREN is a learning-through-games model utilizing modified tools to improve the mentally disabled students' motor skills, exercise courage, and inciting interaction and cooperation among students. The method being used is circuit training method. In the circuit, there are 7 bases, each base with its own different modification and movement tools. In addition, at each base there are three different levels of difficulty. The existence of various modification tools and movements is expected to attract students' attention, hence increasing students' learning motivation.

The purpose of this learning model is to provide an alternative of variations of learning material for teacher and improving gross motor skills of mentally disabled students.

\section{METHOD}

\section{A. Research Design}

The technique being used in this research was a development research. The research was carried out for 5 months. According to Gall and Borg, development research is oriented to develop and validate the products used in education [16]. Broadly speaking development model is described as follows: 


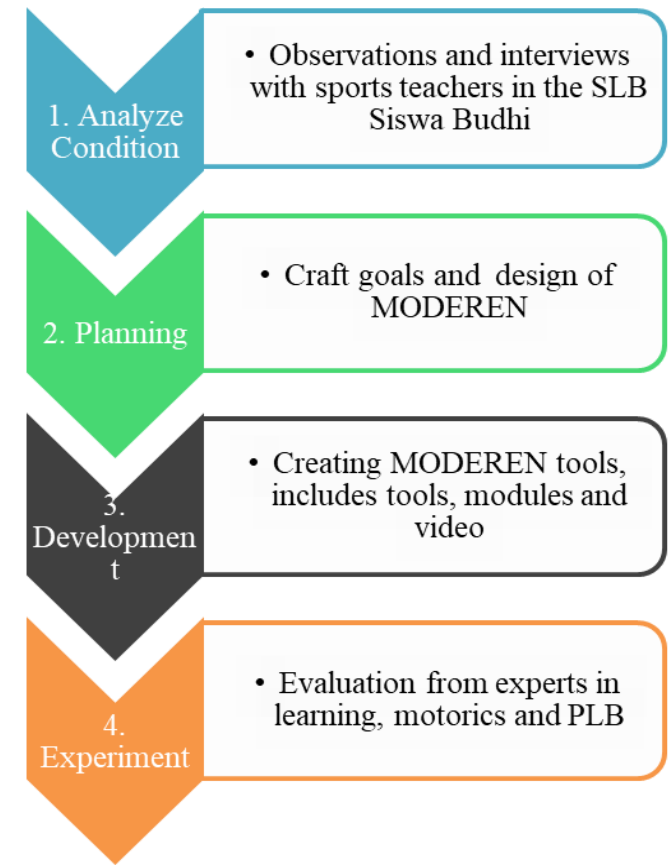

Fig. 1. Research design.

Subject tis research was performed using purposive sampling technique. The instruments were measured for their effectiveness in MODEREN model on learning to improve gross motor skills of mentally retarded students in Siswa Budhi Extraordinary School Surabaya.

\section{RESULTS}

\section{A. MODEREN Modified Tools and Modules}

MODEREN modified tools have been created and validated by experts. Validation was performed to assess feasibility of the tools applied in learning using the MODEREN model. Validation was carried out by 5 validators, whom are experts in their respective fields. The validators are expert in motoric learning, Adaptive Sports Education, learning media, Social Psychology and Orthopaedic Children with Mental Retardation, and experts in Adaptive Guidance and Sports.

\section{B. Application of MODEREN}

The application of MODEREN in learning was carried out for 5 days. The first meeting was conducted by the teacher with the assistance of the team to mentally retarded students by giving examples of movements that would be carried out by them. In the second meeting, the teacher gave pre-tests to mentally retarded students to find out their initial motor skills and it was continued with learning starting from base 1 to base 4. In the third meeting, the teacher conducted learning starting from base 5 to base 7 . The next meeting, the teacher conducted learning starting from base 1 to base 7 . In the last meeting, the teacher gave a post-test to measure the motoric skills of mentally retarded students and evaluated the effectiveness of models application on gross motoric skills of mentally retarded students whilst collecting star pins and certificates. The team then analysed the data from the results of the pre-test and posttest results. The results could be seen in the following diagram:

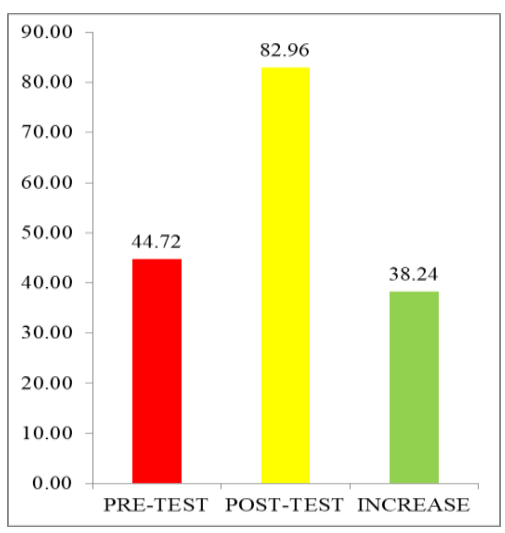

Fig. 2. Percentage of the increase of outcomes after using MODEREN model.

The results showed that application of MODEREN model increased the gross motoric skill of students with mental retardation by $38,24 \%$. The results of the study can explain that the use of modification tools makes it easy for children with disabilities to carry out the learning process in physical education. Based on observations when learning to use MODEREN students feel happy and their motor activity increases. Students practice with their peers, even unwittingly doing motor movement activities by moving places to play games at each post. The teacher feels that by applying this model, students look more active and independent. Provide opportunities that are given, will develop the motor skills of individuals who experience mental disorders [16]. The teacher also believes that the existence of a learning model like this can make physical education learning very suitable for fostering students' interest in doing physical activities individually. Sports activities provide the benefit of developing student movement coordination. When students feel happy with the media that is applied, the messages and information that they want to convey can be captured well by students. A learning is said to achieve the learning objectives if the learning process is in accordance with the characteristics of students. This study shows that if the application of media is adjusted to the needs of students, the results will have a good impact on students. Previous research stated that after activities in a fun environment, autistic children increase social interactions and friendship with their peers, feelings of loneliness decrease. Motor skills will also increase if students continue to practice and improve motor movements.

\section{CONCLUSIONS}

MODEREN model improves gross motor skills, confidence, and cooperation in mentally retarded students in Siswa Budhi Extraordinary School Surabaya. It is potential for another extraordinary school in Surabaya to apply this model in learning process in hopes of getting similar results.

\section{ACKNOWLEDGMENT}

Acknowledgments are gratefully delivered by us to the Ministry of Research, Technology, and Higher Education of the Republic of Indonesia, which has funded MODEREN in 2018, Surabaya State University which has given us moral 
with significant cognitive disabilities," Exceptional children, vol. 74(4), pp. 407-432, 2008.

support and facilitated the sharing thereby increasing our scientific knowledge, Mr / Ms Deans of Faculty, lecturers, and the Faculty of Sport Sciences which has given us material support and motivation, Siswa Budhi Extraordinary School Surabaya, which has supported the implementation of our program, and the Publisher who has helped our publication activities.

\section{REFERENCES}

[1] U.Y. Utari, N. Indahwati, "Upaya meningkatkan gerak dasar lokomotor anak tunagrahita ringan melalui permainan tradisional," J Pendidik Olahraga dan Kesehatan, vol. 3(2), pp. 279-82, 2015.

[2] O.A. Fakolade, S.O. Adeniyi and A. Tella, "Attitude of teachers towards the inclusion of special needs children in general education classroom: The case of teachers in some selected schools in Nigeria," International Electronic Journal of elementary education, vol. 1(3), pp. 155-169, 2017.

[3] S. Kosari, R. Hemayat-Talab, E. Arab-Ameri and F. Keyhani, "The effect of physical exercise on the development of gross motor skills in children with attention deficit/hyperactivity disorder," Zahedan Journal of Research in Medical Sciences, vol. 15(2), pp. 74-78, 2013.

[4] B. Delphie, "Matematika untuk anak berkebutuhan khusus," PT Intan Sejati Klaten, 2009.

[5] L.S. Vygotsky, "The dynamics of the schoolchild's mental development in relation to teaching and learning," Journal of cognitive education and psychology, vol. 10(2), pp. 198-211, 2011.

[6] D.M. Browder, F. Spooner, L. Ahlgrim-Delzell, A.A. Harris \& S. Wakemanxya, "A meta-analysis on teaching mathematics to students
[7] E. Kosasih, "Cara bijak memahami anak berkebutuhan khusus," Bandung: Yrama Widya, 2012.

[8] W.L. Heward, "Exceptional children," Prentice Hall, 2002.

[9] R.L. Simpson, R.L. Peterson and C.R. Smith, "Critical educational program components for students with emotional and behavioral disorders: Science, policy, and practice," Remedial and Special Education, vol. 32(3), pp. 230-242, 2011.

[10] M. Clark and P. Parette, "Student athletes with learning disabilities: A model for effective supports," College Student Journal, vol. 36(1), 2002.

[11] H.V. Praag, A.F. Schinder, B.R. Christie, N. Toni, T.D. Palmer, F.H. Gage, "Functional neurogenesis in the adult hippocampus," Nature, vol. 415(6875), p. 1030, 2002.

[12] W.J. Harvey and G. Reid, "Attention-deficit/hyperactivity disorder: A review of research on movement skill performance and physical fitness," Adapted Physical Activity Quarterly, vol. 20(1), pp. 1-25, 2003.

[13] D.R. Shapiro and L.K. Sayers, "Who does what on the interdisciplinary disabilities?," Teaching Exceptional Children, vol. 35(6), pp. 32-38, 2003.

[14] M. Yanardag, I. Yilmaz and O. Aras, "Approaches to the Teaching Exercise and Sports for the Children with Autism," International Journal of Early Childhood Special Education, vol. 2(3), 2010.

[15] M.R. Oedjoe, B.N. Bunga, "Meningkatkan kemampuan motorik kasar melalui permainan tradisional "SIKODOKA" bagi anak usia dini berlatar belakang tuna grahita," J Ilm Visi, vol. 11(2), pp. 73-80, 2016.

[16] M.D. Gall, W.R. Borg, J.P. Gall, "Educational research: an introduction," Longman Publishing, 1996. team: Regarding physical education for students with 